\title{
植物におけるホスホリパーゼDの生理機能 The Role of Phospholipase D in Plant
}

\section{山口 武志}

農業・食品産業技術総合研究機構 中央 農業総合研究センター作物開発研究領域 T 943-0193

新潟県上越市稲田 1-2-1

\section{Takeshi YAMAGUCHI}

National Agricultural Research

Center, National Agricultural and

Food Research Organization

Inada 1-2-1, Joetsu, Niigata 943-0193, Japan

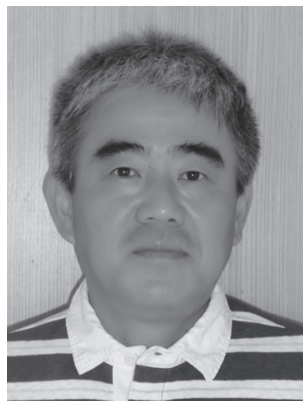

山川 博幹

農業・食品産業技術総合研究機構 中央 農業総合研究センター作物開発研究領域

T 943-0193

新潟県上越市稲田 1-2-1

Hiromoto YAMAKAWA

National Agricultural Research

Center, National Agricultural and

Food Research Organization

Inada 1-2-1, Joetsu, Niigata 943-0193, Japan

\author{
黒田 昌治 \\ 農業. 食品産業技術総合研究機構 中央 \\ 農業総合研究センター作物開発研究領域 \\ T 943-0193 \\ 新潟県上越市稲田 1-2-1 \\ Masaharu KURODA \\ National Agricultural Research \\ Center, National Agricultural and \\ Food Research Organization \\ Inada 1-2-1, Joetsu, Niigata 943-0193, Japan \\ 羽方 誠 \\ 農業・食品産業技術総合研究機構 中央 \\ 農業総合研究センター作物開発研究領域 \\ T 943-0193 \\ 新潟県上越市稲田 1-2-1

Makoto HAKATA
National Agricultural Research
Center, National Agricultural and
Food Research Organization
Inada 1-2-1, Joetsu, Niigata 943-0193, Japan

論文要旨：動植物の様々な生理機能にリン脂質代謝が重要な役割を果たしていることが知られている。植物で は様々な環境ストレスやホルモンの情報伝達にホスホリパーゼ D (PLD) が関与していることが報告されている。 植物の PLD はシロイヌナズナで 12 個, イネで 17 個の遺伝子が存在し, その構造, 生化学的特性からいくつか の夕イプに分類されている。イネにおける PLD の生理機能を解析するために，個々の遺伝子の発現を RNA干 渉（RNAi）で抑制した Knockdown（KD）系統を形質転換で作出しその表現形質を解析した結果，イネの PLD の一つである OsPLD $\beta 1$ が抑制された OsPLD 1 1-KD 系統が, 病原菌感染が無い状態で防御応答を誘導し, 病害 抵抗性が大幅に強化されることが明らかになった。これまで植物の PLD は防御応答の誘導の正の制御に関与し ていることが示されていたが，OSPLD 1 が負の制御に関わっていることは，植物では夕イプの異なる PLD が環 境応答で異なる機能を有することを示唆している。本稿では植物における PLD の生理機能について解説する。

Abstract: The phospholipids metabolism has been known to play an important role in both animals and plants. In plants, phospholipase D (PLD) has been suggested to be involved in many plant cellular processes, such as signaling for stress and hormone responses. Plant PLDs are a family of heterologous enzymes and 12 PLD genes in arabidopsis and 17 ones in rice were reported. They can be classified into several types based on their gene architectures, sequence similarities, domain structures, and biochemical properties. To examine the physiological function of PLD in rice, we made knockdown plants for each PLD isoform by introducing gene-specific RNAi constructs. One of them, OsPLD $\beta 1$ knockdown plants showed the accumulation of reactive oxygen species in the absence of pathogen infection. RT-PCR and DNA microarray analyses revealed that the knockdown of OsPLD $\beta 1$ resulted in the up-/down-regulation of more than 1,400 genes, including the induction of defense-related genes such as PR protein genes and WRKY/ERF family transcription factor genes. HR-like cell death and phytoalexin production were also observed at a later phase of growth in the OsPLD $\beta 1$-knockdown plants. These results indicated that the $O s P L D \beta 1$-knockdown plants spontaneously activate the defense responses in the absence of pathogen infection.

Key words: phospholipase D, rice, RNAi, defense response, reactive oxygen species, phytoalexin 


\section{1 はじめに}

動植物のホルモンや環境応答の生理機能にリン脂質代 謝が重要であることが知られている。動物においてはホ ルモンの作用によりホスホリパーゼ C (PLC) が活性化 され，その結果としてイノシトールリン脂質の代謝によ り形成される Diacylglycerol (DAG) と Inositol triphosphate (IP3) がそれぞれ Protein kinase C (PKC) の活性化と細胞内カルシウム濃度の上昇をトリガーし, 特にカルシウムイオンに関わる細胞内のシグナル伝達を 担っていることが明らかになっている ${ }^{1,2)}$ 。これらの研 究以来, 動物においては様々な生理機能にリン脂質代謝 が重要な役割を果たしていることが確立されている。そ の後, 植物においても病原菌の感染などの様々な環境変 化に対する応答，植物ホルモンに対する応答にリン脂質 代謝が活性化され，その結果形成される Phosphatidic acid（PA）が様々な生理機能を有していることが明ら かになってきている(Fig. 1) ${ }^{3)}$ 。PA の生理機能としては, 活性酸素の生成 ${ }^{4-6)}$, Mitogen-activated protein kinase (MAPK) の活性化 ${ }^{7)}$ などが明らかにされ，さらにPAの 幾つかのターゲット蛋白質としては, Protein kinase ${ }^{8-10)}$, Protein phosphatase ${ }^{11)}$, Phosphoenolpyruvate carboxyl$\operatorname{ase}^{12)}$ などが生化学的に報告されている。植物の場合は 生体膜リン脂質から PA を形成する二つのルートが知ら れていて, Phosphatidylcholine (PC), Phosphatidylethanolamine（PE）などの主要リン脂質からホスホリ

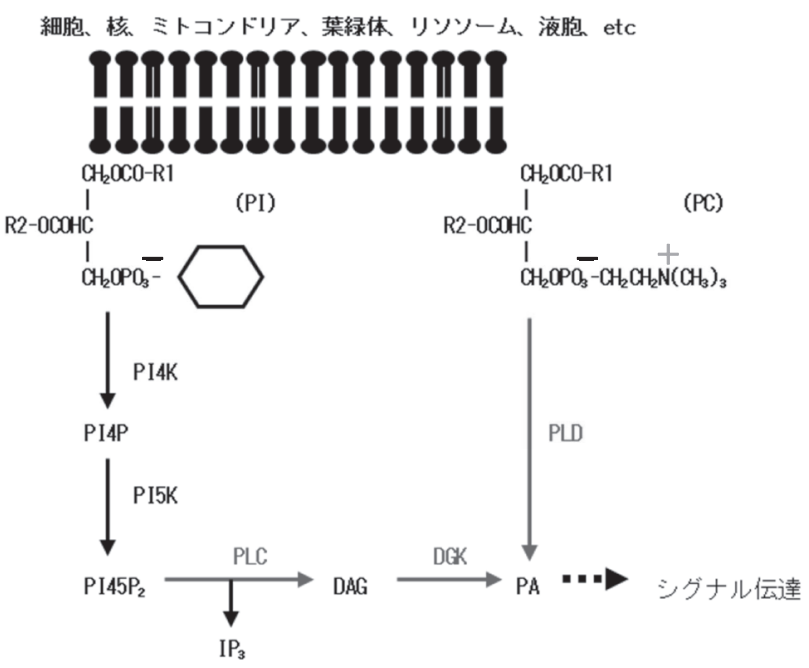

Fig. 1 植物のリン脂質の主要代謝モデル。PC: Phosphatidylcholine, PI: Phosphatidylinositol, PI4P: Phosphatidylinositol-4-phosphate, PI45 $\mathrm{P}_{2}$ : Phosphatidylinositol-4,5-bisphosphate, $\mathrm{IP}_{3}$ : Inositol-tri-phosphate, DAG: Diacylglycerol, PA: Phosphatidic acid, PI4K: Phosphatidylinositol-4-kinase, PI5K: Phosphatidylinositol-5-kinase, PLC: Phospholipase C, DGK: Diacylglycerol kinase, PLD: Phospholipase D
パーゼ D (PLD) の作用で直接 PA に変換する PLD 経 路と, イノシトールリン脂質から PLCの活性化により 形成されたDAGが Diacylglycerol kinase（DGK）によ りPA に変換される PLC-DGK 経路が知られている (Fig. 1)。このうち本稿では植物の PLD の生理機能を中心に 紹介する。

\section{2 植物のホスホリパーゼ D}

PLD は植物で発見され植物の代表的なホスホリパー ゼであり, 生体膜リン脂質を PA と Choline などの塩基 に分解する酵素である。PLD はその基質に低濃度の 1-Butanol 存在下で Phosphatidylbutanol を同時に生成す ることから, PLDの生理機能が特異的に阻害されるの で ${ }^{13)}$ ，植物の生理機能への関わりが検出し易いため様々 な生理機能との関与が報告されている（補足：PLDは 1-アルコール存在下では, PA などと加水分解反応と塩 基交換反応の両方を触媒し, Phosphatidyl-アルコール を産生する。Ethanol存在下ではPhosphatidylethanol を, 1-Butanol 存在下では Phosphatidylbutanol を産生する が，PLDの機能を阻害する研究では通常 1-Butanol が用 いられている。）。その主なものとしては各種環境ストレ スのシグナル伝達や植物ホルモンの応答 ${ }^{3,14)}$, 枯死過程 における細胞膜の分解 ${ }^{15)}$, 生体膜の架橋 ${ }^{16}$ 17) などが報 告されている。

植物の PLD 遺伝子が最初にクローニングされて以来 ${ }^{18)}$, シロイヌナズナでは 12 個の, イネでは 17 個の PLD 遺 伝子の存在が示唆されている $(\text { Fig. 2 })^{19)}$ 。ちなみに動物 は 2 個, 酵母は 1 個のPLD 遺伝子を持っている ${ }^{20)}$ 。 PLD タンパク質はシロイヌナズナとイネで詳細に研究 されていて, その構造上の特徵から PLD $\alpha, \beta, \gamma, \delta, \varepsilon$, らの 6 種類のクラスに分類されている。一方イネにおい てはPLD $\alpha, \beta, \delta, \varepsilon, \eta, \theta, \zeta, \imath$ の 8 種類のクラスに 分類されている。PLD はまたそのドメイン構造の相違 から C2-PLD, PX/PH-PLD，その他に分類することも ある。この分類では PLD $\zeta$, PLD 1 以外のすべてのクラ スの PLD がC2-PLD, PLDלが PX/PH-PLDに分類さ れている。イネに存在する PLDıだけがどちらの PLD にも分類できない (Fig. 2)。ちなみに動物の 2 個の PLD はいずれも PX/PH-PLD である 20,21)。PLD の酵素 としての生化学的な特性はシロイヌナズナで詳細に検討 され, クラスごとにPLD の活性化に対するカルシウム 要求性, 活性化に対する Phosphatidylinositol-4,5-bisphosphate $\left(\mathrm{PIP}_{2}\right)$ の要求性, さらに基質特異性がそれ ぞれ異なることが報告されている。特に基質特異性の相 違についてはPCと PEとの比較において PLD $\alpha$ は PC $>\mathrm{PE}, \mathrm{PLD} \beta$ は $\mathrm{PC}=\mathrm{PE}, \mathrm{PLD} \gamma$ と $\mathrm{PLD} \delta$ は $\mathrm{PE}>\mathrm{PC}$, 

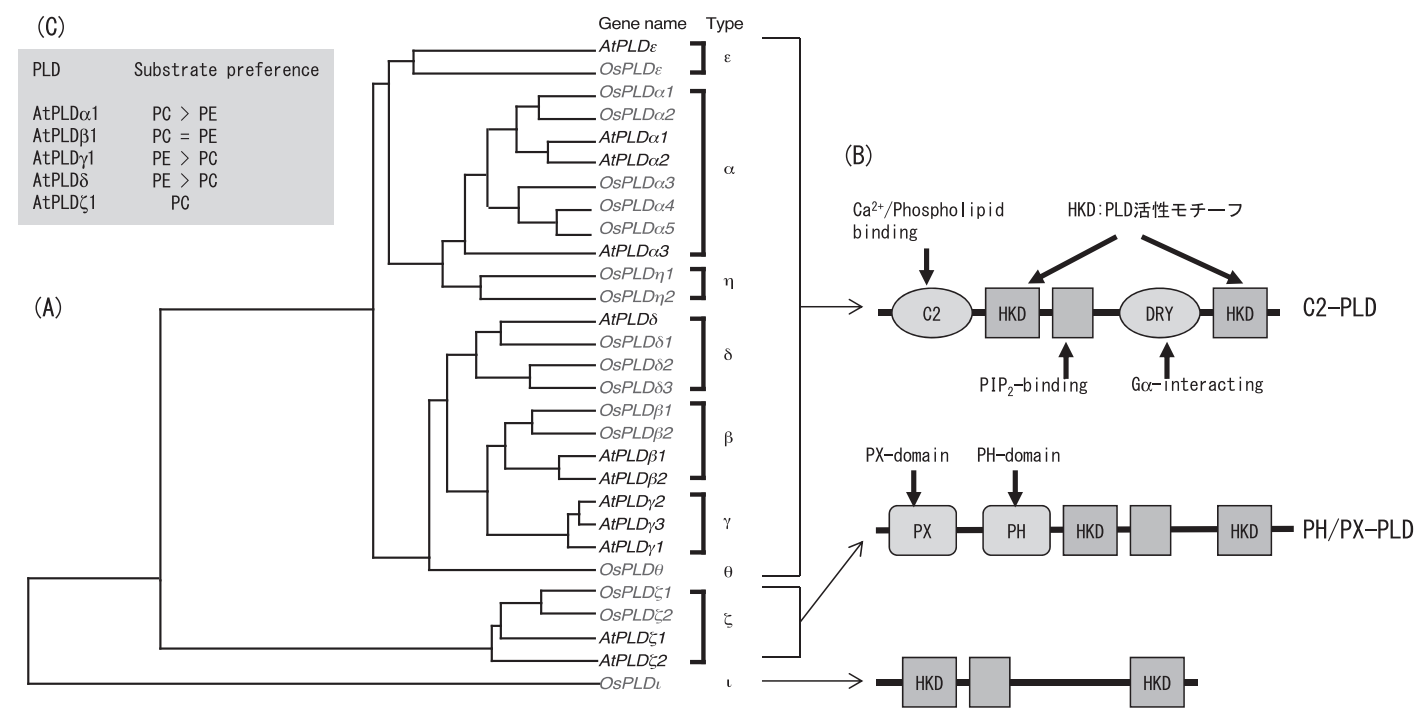

Fig. 2 イネ (Os) とシロイヌナズナ（At）のPLD 遺伝子の系統樹（A），ドメイン構成（B)，シロイヌナズナ PLDの基質特異 性 (C)

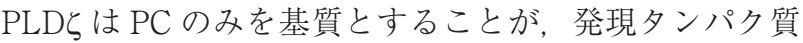
を用いた実験系で認められている（Fig. 2)。

\section{3 植物の PLD の生理機能}

これまでシロイヌナズナとイネにおいて幾つかの PLDの生理機能が遺伝子発現を抑制したKnockdown （KD）系統または遺伝子が欠損したKnockout（KO）系 統と, 野生株（Wild type）との表現形質を比較した様々 な栽培生理試験において報告されている。PLDaについ てはアブシジン酸（ABA）やエチレンに対する応答 ${ }^{22)}$, 活性酸素の生成 ${ }^{4)}$, 乾燥ストレス耐性 ${ }^{23)}$, 凍結耐性 ${ }^{24)}$, 種子の品質劣化 ${ }^{25,26)}$ ，浸透圧ストレス耐性 ${ }^{27)}$ ，虫害抵 抗性の誘導 ${ }^{28)}$ に関与することがそれぞれ報告されてい る。PLD $\beta$ については, 防御応答の誘導に対する負の制 御 ${ }^{19)}$ と種子の発芽時の $\mathrm{ABA}$ シグナル伝達 ${ }^{29)}$ に関与す ることが報告されている。PLD $\delta$ についは乾燥耐性の 誘導 ${ }^{30)}$, 微小管の再生 ${ }^{16,17)}$, 凍結, 過酸化水素, UV 耐性の誘導 ${ }^{31}$, 32) に関与することがそれぞれ報告されて いる。PLDלについては根毛の生育とパターン形成 ${ }^{33)}$ と根のオーキシン誘導性反応 ${ }^{34)}$ に関与することが報告 されている。

このような PLD の生理機能が生体膜の機能を変化さ せるだけではなく, PLDの活性化で生じるPA がセカ ンドメッセンジャーとしてシグナル伝達に関与している ものと考えられている。PLD 経路で生成する PAの夕ー ゲットとしては Protein phosphatase である ABI1 (ABA Insensitive 1 蛋白質）が証明されている。シロイヌナズ ナの変異系統を用いた研究から, 植物ホルモンである ABAの種子の発芽の抑制には Protein phosphatase で
ある ABI1 の抑制が必要不可欠であることが知られてお り ${ }^{35)}$ ， ABA の作用により PLD が活性化されることも また知られていた ${ }^{36)}$ 。このシグナル伝達が AtPLDa1 (At: Arabidopsis thaliana. シロイヌナズナ) の活性化 により生成するPAが ABI1に結合し, ABI1の機能を 抑制することにより ABAの機能を伝達していることが 証明されている ${ }^{11)}$ 。こように明瞭に解明された例は これ以外にはないが, PLDの生理機能がPA かその代 謝産物が主にProtein kinaseまたはProtein phosphatase を介して伝達されているものと予想されている。

\section{4 イネ PLD の生理機能}

イネのPLD としてはPLD $\alpha$ と PLD $\beta$ の生理機能が幾 つか明らかになっている。筆者らはイネにおける PLD の生理機能を解析する目的で, 17 種類の PLDのうち PLD 1 を除く 16 種類の PLD 遺伝子の発現を, イネの主 な組織において解析した (Fig. 3)。その結果, OsPLD $\beta 1$, $\alpha 1, \alpha 5$ が解析したほとんどの組織で強く発現していた。 特にOsPLD $\beta 1$ は解析したいずれの組織でも多量に発現 していた。また組織ごとに発現する PLDの種類に違い が観られた。一方, OsPLDE, $\delta 2, \delta 2, \delta 3, \eta 1, \theta$ の発 現レベルは解析した組織では極めて低かった（Fig. 3）。 これらのPLDのイネにおける生理機能を解析するため に，それぞれの遺伝子の発現を抑制するための RNA 干 涉用ベクターをアグロバクテリウムによる間接法でイネ に導入し，それぞれの KD 系統を作出した。これらのイ ネを温室で栽培し，その表現形質を解析した結果， $O S P L D \beta 1$ を抑制した系統 $(O S P L D \beta 1-K D$ 系統) だけが, 温室における病原菌を接種しない通常の栽培条件下で, 

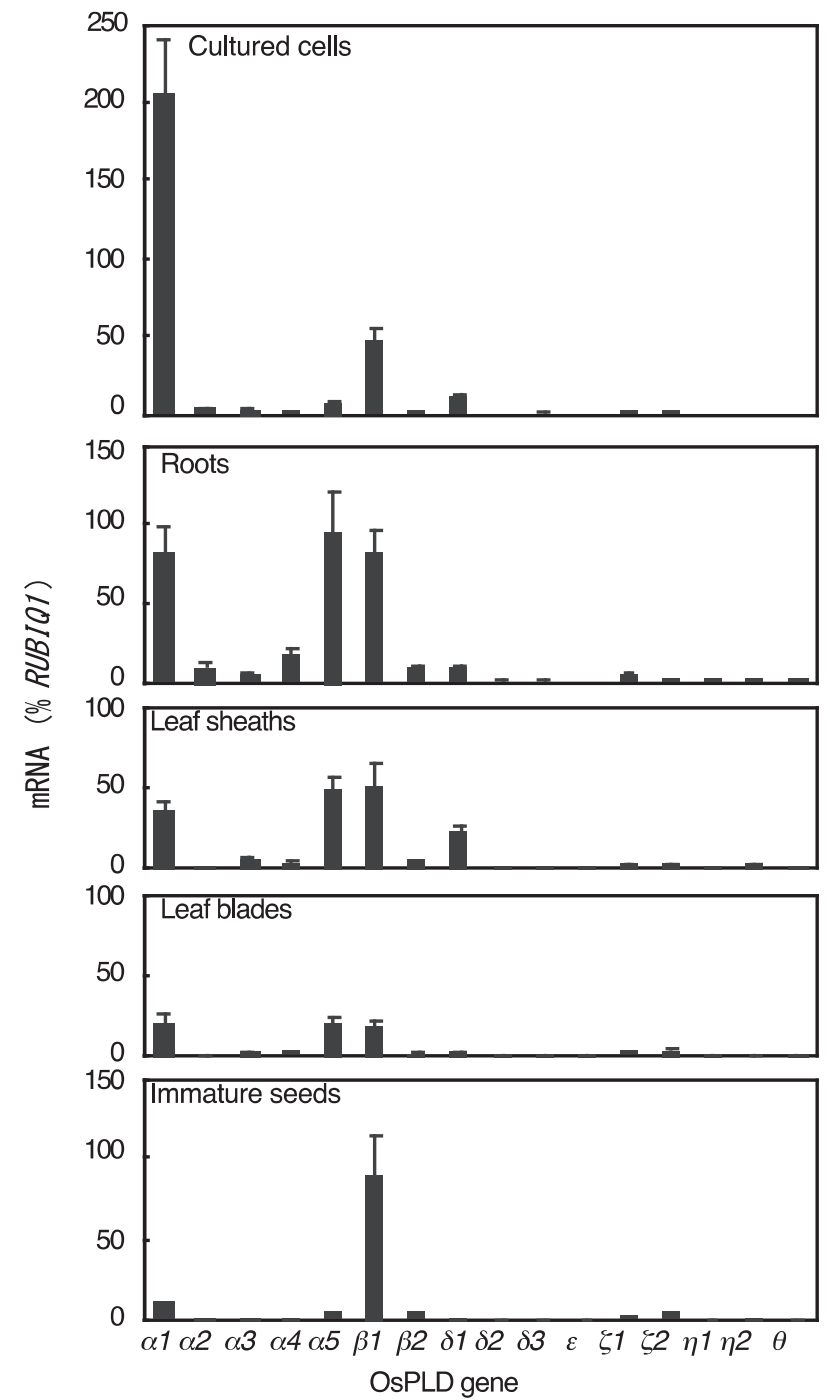

Fig. 3 イネにおける各PLD 遺伝子の発現解析。Roots, Leaf sheaths, Leaf bladesは播種 30 日後, Immature seeds は出穂 10 日後

葉身にあたかも病原菌に感染したかのような疑似病班を 形成することが明らかになった（Fig. 4）。このような表 現形質を示す植物体は疑似病班変異体（Disease lesion mimic mutant：DLMM）と呼ばれ，その多くは病原菌 に対する抵抗性が高まることが知られている。またその 原因遺伝子はLesion mimic gene と呼ばれていて, イネ を含む高等植物で多数報告されている ${ }^{37)}$ 。たとえばイ ネの DLMM として知られている Spl7 と Spl11 の原因遺伝子 はそれぞれ heat stress transcription factor と E3 ubiquitin ligase をコードしていることが報告されている ${ }^{38,39}$ 。

\section{OsPLD B 1-KD は防御応答が誘導されている}

イネなどの高等植物には高等動物のような発達した免 疫システムは備わっていないが, 病原菌やウイルスの感 染に対して, 活性酸素や抗菌物質の産生, 細胞壁の強化,

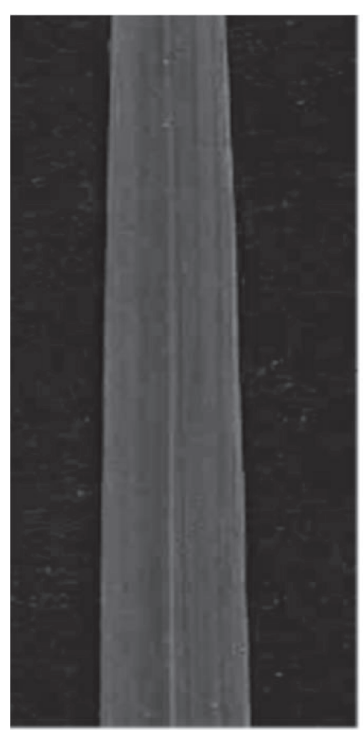

Control

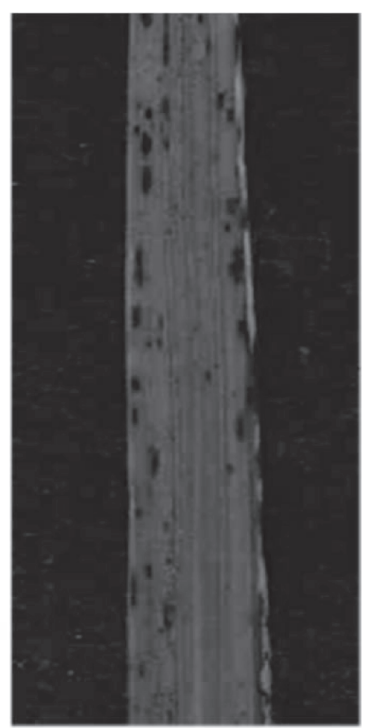

OsPLD $\beta 1-K D(R N A i)$
Fig. 4 OsPLD $\beta 1-\mathrm{KD}$ (RNAi）系統の葉身の疑似病班
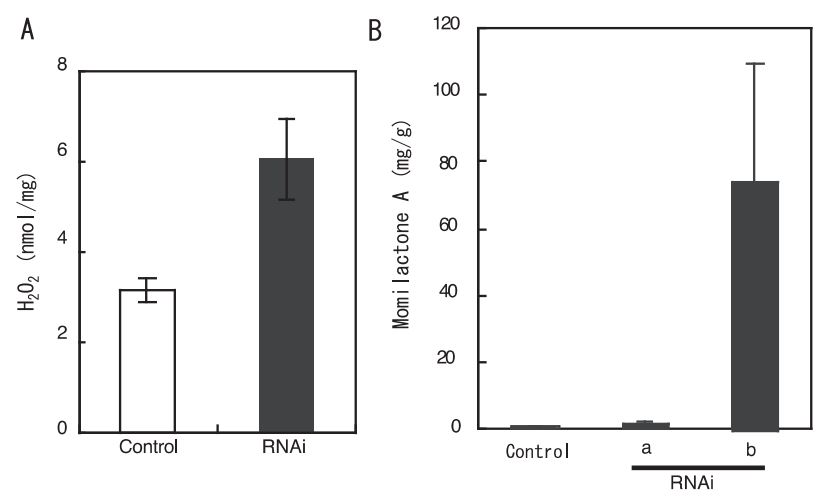

Fig. 5 OsPLD $\beta 11-\mathrm{KD}$ (RNAi) 系統の葉身の過酸化水素量 (A) と Moilactone A 量 (B)。a：疑似病班以外の部 分, $\mathrm{b}$ : 疑似病班部分

防御関連 (PR) タンパク質の誘導, 過敏感反応 (Hypersensitive reaction：HR）の誘導などの幾つかの 生体防御反応を引き起こすことが知られている ${ }^{40,41)}$ 。 植物に病原菌が感染した場合，それらに対して抵抗性を 示す場合はHRを誘導しR型と呼ばれる病班が形成され， 病原菌感染の拡大を阻止することが知られている ${ }^{42)}$ 。 OsPLD B1-KD 系統に現れる疑似病班が $\mathrm{R}$ 型であるため (Fig. 4)，OsPLDB1-KD 系統が病原菌感染時に引き起こ される一連の防御応答が常に誘導されていることが予想 された。それらの解析を行った結果, OsPLDB1-KD 系 統では，葉身に高いレベルの活性酸素が検出され（Fig. $5 \mathrm{~A}$ ，またた疑似病班部分にはイネの代表的な抗菌物質で ある Momilactone A が大量に検出されることが明らか になった（Fig. 5B）。さらに葉身に発現している遺伝子 を解析した結果, 防御応答で発現する Probenazol-in- 


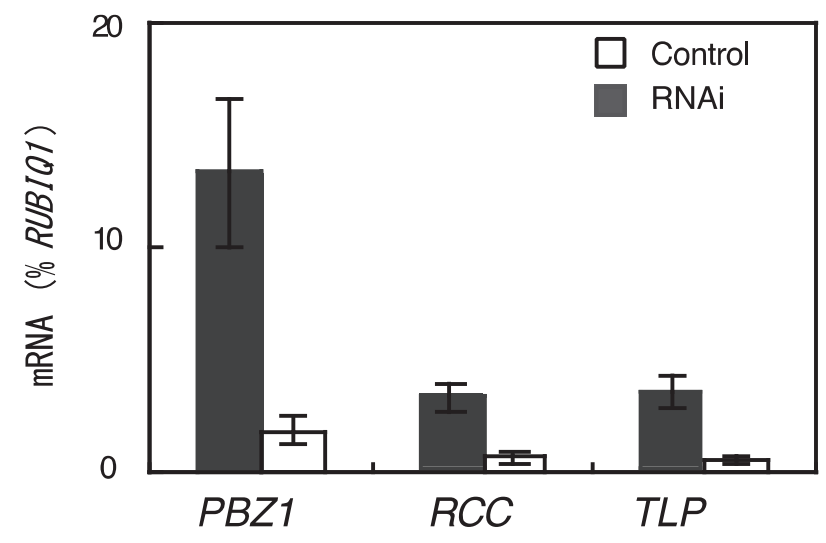

Fig. 6 OsPLD $\beta 1-\mathrm{KD}$ (RNAi) 系統と Control の葉身におけ る PR タンパク質遺伝子の発現解析。PBZ1: Probenazol-inducible protein 1, RCC: Rice chitinase, TLP: Thaumatin-like protein

ducible protein $(P B Z 1)$, Chitinase $(R C C)$, Thaumatin-like protein $(T L P)$ などの PR タンパク質遺伝子が 極めて多く発現していることが明らかになった（Fig. 6)。さらにOsPLD $31-\mathrm{KD}$ 系統の葉身の発現遺伝子をイ ネ 44k-DNA- マイクロアレイで大量に解析した結果, WRKY45などの Pathogenesis-related transcription factor（防御関連転写因子）を多く発現していた ${ }^{19)}$ 。 WRKY45 はイネの病原菌感染に対して圧倒的な抵抗性 を誘導できることが報告されている ${ }^{43)}$ 。これらの遺伝 子は，主に病原菌に感染した時に特異的に発現するもの であるため, OsPLD 1 1-KD 系統は常時防御応答が誘導 されていることが明らかになった。イネに感染する代表 的な病原菌としては系状菌のいもち病菌 (Pyricularia grisea) と細菌の白葉枯病菌 (Xanthomonas oryzae pv oryzae) が知られていて, OsPLDB1-KD 系統のこれら の病原菌に対する抵抗性を検定した結果，いずれの感染 に対しても抵抗性が大幅に増加することが明らかになっ た ${ }^{19)}$ 。従って, OsPLDB1 (Os：Oryza sativa.イネ)は イネの防御応答と病害抵抗性の誘導の Negative regulator として機能することが明らかになった ${ }^{19)}$ 。

\section{$6 \operatorname{PLD} a$ と PLD $\beta$ の生理機能の相違}

しかしながら OsPLD 1-KD 系統はなぜ防御応答が常 に誘導されるのか? そもそもなぜ活性酸素が蓄積される のか? といった問題は依然不明である。これまでの研究 では PLD の活性化で生じる PA はイネやシロイヌナズ ナなどの植物だけではなく, ヒトの好中球に対しても活 性酸素生成の Positive regulator であることが報告され

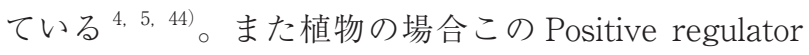
として作用するのが $\alpha$ タイプの PLD であることも示唆 されている。イネの培養細胞を用いた研究ではキチンオ

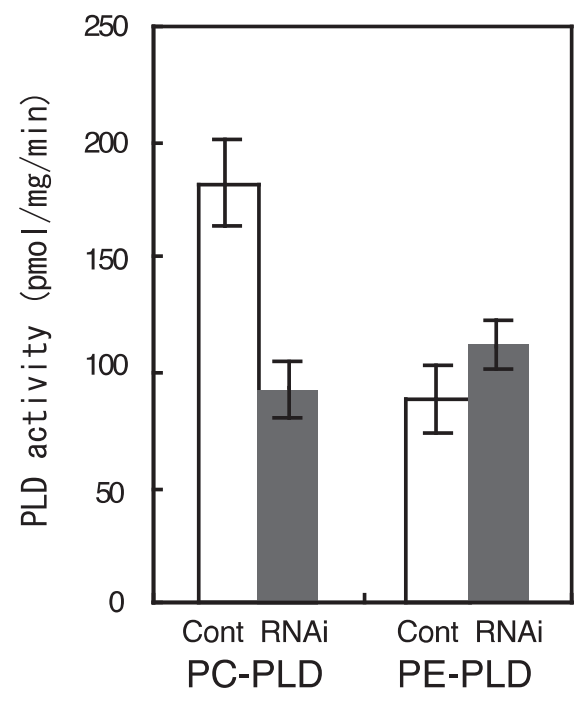

Fig. 7 OsPLD 1 1-KD (RNAi) 系統と Control (Cont) の葉 身における PLD 活性。PC-PLD: Phosphatidylcholinespecific PLD 活性, PE-PLD: Phosphatidylethanolaminespecific PLD 活性

リゴ糖がイネの活性酸素生成を誘導することが知られて いるが，そのシグナル伝達が PLD の活性化を伴うこと， 活性化されるPLD が $\alpha$ タイプであることが報告されて いる ${ }^{6)}$ 。 $\alpha$ タプの PLD が活性酸素や防御応答の誘導 の Positive regulator として機能していることが示唆さ れている一方, OsPLDß1 は明らかに Negative regulator として機能している。さらにOSPLD 1 1-KD 系統と WTの葉身に扮けるPLD 活性の変化を定量した結果, OsPLD 1 1-KD 系統では PC を分解する活性が大幅に低 下していた（Fig. 7)。PLD 活性が低下しているにもか かわらず，活性酸素が増加するという事実はこれまでの 報告とは全く逆の結果を示している。PLD $\alpha$ と PLD $\beta$ は 同じPLD であるにもかかわらず，全く逆の生理機能を 有する理由は不明であるが, 有力な可能性の一つとして PLD 分子の細胞内の局在性の相違が考えられる。イネ の OsPLDa1 は細胞壁, 細胞膜, クロロプラストに存在 し， $\alpha 4$ と $\alpha 5$ はクロロプラストに存在することが報告さ れている ${ }^{45)}$ 。一方, トマトでクローニングされた LePLD $\beta 1$ (Le : Lycopersicon esculentum. トマト) は蛍 光蛋白質である GFP との融合タンパク質の細胞内の局 在解析から, LePLDb1 が細胞質内の特に小胞の周辺に 存在することが報告されている ${ }^{46)}$ 。このような細胞内 の局在性の相違が PLD $\alpha$ と PLD $\beta$ の生理機能の相違に 反映しているものと思われる。

\section{7 おわりに}

本稿では植物の環境生理に関わるPLD の機能につい て紹介したが，植物の生育と環境応答におけるリン脂質 
代謝を伴う生理機能に対しては, PLC や Phospholipase A（PLA）が同様に重要な役割を有していることが多数 報告されており，リン脂質代謝が植物の様々な生理機能 を制御していることが明らかになっている。

\section{文 献}

1) Nishizuka Y, Nature, 306, 693-8 (1984).

2) Berridge MJ \& Irvine RF, Nature, 312, 315-21 (1984).

3) Testerink C \& Munnik T, Trends in Plant Sci., 10, 368-75 (2005).

4) Sang Y et al., Plant Physiol., 126, 1449-58 (2001).

5) Yamaguchi T et al. Physiol Plant., 118, 361-70 (2003).

6) Yamaguchi T et al. Plant Cell Physiol., 46, 579-87 (2005).

7) Lee S et al., Plant J., 26, 479-86 (2001).

8) Anthony RG et al., EMBO J., 23, 572-81 (2004).

9) Deak M et al., FEBS Lett., 451, 220-6 (1995).

10) Farmer PK \& Choi JH, Biochim Biophys Acta, 1434, 6-17 (1999).

11) Zhang $W$ et al., Proc Natl Acad Sci USA., 101, 9508-13 (2004).

12) Teasterink C et al., Plant J., 39, 527-36 (2004).

13) Munnik T, Trends in Plant Sci., 6, 227-33 (2001).

14) Wang X, Plant Physiol., 139, 566-73 (2005).

15) Ryu SB \&Wang X, Plant Physiol., 108, 713-19 (1995).

16) Dhonukshe et al., Plant Cell, 15, 2666-79 (2003).

17) Gardiner et al., Plant Cell Physiol., 44, 687-96 (2003).

18) Wang X et al., J Biol Chem., 269, 20312-17 (1994).

19) Yamaguchi T et al., Plant Physiol., 150, 308-19 (2009).

20) Elias M et al., BMG Genomics, 3, 1-15 (2002).
21) Qin C \& Wang X, Plant Physiol., 128, 1057-68 (2002).

22) Fan L et al., Plant Cell, 9, 2183-96 (1997)

23) Song Y et al., Plant J., 28, 135-44 (2001).

24) Welti R et al., J Biol Chem., 277, 31944-2002 (2002).

25) Devaiah SP et al., Plant J., 50, 950-57 (2007).

26) Suzuki Y, Crop Science, 51, 567-73 (2011).

27) Hong $Y$ et al., Plant Cell, 20, 803-86 (2008).

28) Qi J et al., Plant Physiol., 157, 1987-99 (2011).

29) Li G et al., Cell Research, 17, 8881-94 (2007).

30) Katagiri T et al., Plant J., 26, 595-605 (2001).

31) Zhang W et al., Plant Cell, 15, 2285-95 (2003).

32) Li W et al., Nature Biotech., 22, 427-33 (2004).

33) Ohashi Y et al., Science, 300, 1427-30 (2003).

34) Li G \& Xue HW, Plant Cell, 19, 281-95 (2007).

35) Leuing J et al., Science, 264, 1148-52 (1994).

36) Jacob T et al., Proc Natl Acad Sci USA., 96, 12192-97 (2004).

37) Lorrain S et al., Trends in Plant Sci., 8 263-71 (2003).

38) Yamanouchi U et al., Proc Natl Acad Sci USA., 99, 7530-35 (2002).

39) Zeng LR et al., Plant Cell, 16, 2795-808 (2004).

40) Boller T., Annu Rev Plant Physiol Plant Mol Biol., 46, 189-214 (1995).

41) Dangl JL \& Jpnes JDG., Nature, 441, 826-33 (2001).

42) Takahashi A et al., Plant J., 17, 535-45 (1999).

43) Shimono M et al., Plant Cell, 19, 2064-76 (2007).

44) Qualliotine-Mann D et al., J Biol Chem., 268, 23843-49 (1993).

45) McGee JD et al., Plant Cell Physiol., 44, 1013-26 (2003).

46) Bargmann BOR et al., Plant J., 45, 358-68 (2006). 